\title{
Taxing Income from Illegal Activity: The Kenyan Perspective
}

\author{
Eva Maina and Edward Paranta *
}

\begin{abstract}
Increasingly, states are being called upon to act on illicit financial flows with respect to taxation. In a recent decision, the Court of Appeal of Kenya held that illegal income is taxable under the Kenyan law. There are various arguments for and against taxation of illegal income. As well as arising issues such as deductibility of expenses incurred in the process of income generation, how it relates with the right against self-incrimination and the role of tax law in reinforcing the criminal justice system. This essay is an analysis on whether illegal income in Kenya should be subjected to taxation. The contribution surmises that while taxation of such income may reap benefits, caution must be exercised in order to protect the right against self incrimination.
\end{abstract}

\section{Introduction}

On 15 April 2016, the Court of Appeal of Kenya rendered a landmark ruling. In the seminal case of Republic $v$ Kenya Revenue Authority ex parte Yaya Towers Limited, ${ }^{1}$ the Kenya Revenue Authority (KRA) sought to have an employee of the applicant remit his income tax. Despite finding the employee's employment contract to be illegal, the court proceeded to hold that income accrued from the said contract was liable to taxation. For the first time in Kenya, income derived from illegal activity was held to be taxable pursuant to the provisions of the Income Tax Act of Kenya. ${ }^{2}$ As in many other countries, the debate as to taxability of illegal income has found its way into Kenya's judiciary. This decision opened a plethora of issues, which the court may not have anticipated. This paper delves into the definition of income provided in the Act, the court's interpretation of

* The Authors are Diploma students at the Kenya School of Law and Graduate Assistants at the Strathmore University Law School, in Nairobi Kenya

(2008) eKLR.

Kenya Revenue Authority v Yaya Towers Limited (2016) eKLR. 
the same and whether income generated from illegal activity falls within the law's purview. The question as to whether or not a criminal should be allowed to deduct expenses incurred in the process of procuring the said illegal business is also dealt with. The link between the criminal justice system especially, the right not to self-incriminate ${ }^{3}$ and the taxability of income generated from crime will be examined and finally, the authors analyse the use of tax law to reinforce criminal law. Since the issues raised above are not unique to Kenya, it is important to tackle them with reference to other jurisdictions that have experienced similar problems.

\section{Is income from illegal activity taxable in Kenya?}

Lord McNaghten defined income tax as a tax on income irrespective of other considerations, notably, legality. Whether one has fixed property or lives by his wits he contributes to the tax if his income is above the prescribed limit. ${ }^{4}$

Section 3(1) of the Income Tax Act of Kenya stipulates as follows: 'Subject to, and in accordance with, this Act, a tax to be known as income tax shall be charged for each year of income upon all the income of a person, whether resident or non-resident, which accrued in or was derived from Kenya.'

Pursuant to section 3(1) above, there are two requirements requisite for the income tax to be levied: one, there has to be income; and two, the said income must have been accrued in or derived from Kenya. The reason for the cancellation is, the requirements arre already easily derived from the statute. The question as to what constitutes income can further be viewed from two perspectives: (1) the legality and illegality of the amount in question or (2) the source of taxable income. The former, as we shall see, is not an easy question to answer. With regards to the latter, the Act provides for taxation of: all income from businesses, ${ }^{5}$ income from employment, ${ }^{6}$ income from the use of property, ${ }^{7}$ income from management or professional fees, royalties, interest and rents. ${ }^{8}$ The

Article 50(2) (1), Constitution of Kenya (2010).

London County Council \& Others v The Attorney General (1901), The United Kingdom Court of Appeal as adopted by the court in Pili Management Consultants Ltd $v$ Commissioner of Income Tax, Kenya Revenue Authority (2010) eKLR.

Section 4, Income Tax Act (Chapter 470).

Section 5, Income Tax Act (Chapter 470).

Section 6, Income Tax Act (Chapter 470).

Section 10, Income Tax Act (Chapter 470). 
scope of this article is confined to income that meets the definition of income under the Income Tax Act but tainted by an illegality. As held in Pickfordv Quirke, ${ }^{9}$ the repeated nature of transactions is key in ascertaining whether the amount in question is liable to income tax or not. For example, income derived from a sporadic loot would not qualify as income under the Act, but, income derived from embezzlement by a career embezzler, save for the question of illegality would qualify as income from a business. ${ }^{10}$

The Act uses the phrase 'all income', ${ }^{11}$ and at no place does it qualify the nature of income to be either legal or illegal. This leaves a wide margin for interpretation, illegally obtained income as well as legally obtained income may very well fit the description 'all income'. In Republic v Kenya Revenue Authority ex parte Yaya Towers Limited, ${ }^{12}$ the Kenya Revenue Authority sought to have an employee of the applicant remit his income tax, the court found the employee's employment contract to be illegal. The High Court further held that the Kenya Revenue Authority cannot use an illegal relationship to assess tax as that would be contrary to public policy. ${ }^{13}$ In arriving at this conclusion, the court was guided by several judicial decisions, among them Lord Mansfield's proposition in Holman v Johnson ${ }^{14}$ where he stated that no court will lend its aid to a man who founds his cause of action upon an immoral or illegal act. ${ }^{15}$

The Kenya Revenue Authority proceeded to file an appeal at the Court of Appeal, the highest court in Kenya at the time. A three-judge bench of the Court of Appeal held that whether a business is illegal or services obtained were rendered by an illegal entity, it is still subject to tax for two reasons; firstly, holding otherwise would entitle a wrong doer to benefit from illegal profits earned from unlawful business and, on top of that, be exempted from taxation. It would be an absurdity to tax the gains of an honest man while the dishonest escape taxation. Secondly, if profits of an illegal business were not taxable, honest taxpayers would be incentivised to taint their businesses with an illegality for purposes of securing exemption from taxation. ${ }^{16}$

\footnotetext{
Pickford v Quirke (1927), The United Kingdom Court of Appeal.

10 Section 2 \& 4, Income Tax Act (Chapter 470); Rutkin v United States (1952), The Supreme Court of the United States; James v United States (1961), The Supreme Court of the United States.

11 Section 3(1), Income Tax Act (Chapter 470).

12 (2008) eKLR.

13 Republic v Kenya Revenue Authority ex parte Yaya Towers limited (2008) eKLR.

14 Holman v Johnson (1775), The United Kingdom Court of King's Bench.

15 Holman v Johnson (1775), The United Kingdom Court of King's Bench.

16 Kenya Revenue Authority v Yaya Towers Limited (2016) eKLR.
} 
There are two main arguments that critics often level against taxation of illegal income: that the state would be a silent partner in crime ${ }^{17}$ and that it is a contravention of public policy. ${ }^{18}$ Proponents of the first argument often hold that receipt of proceeds of any profitable activity in the form of taxes makes the state a partner to the given business. ${ }^{19}$ In the same vein, taxing proceeds of crime makes the state a partner to the criminal activity which it sought to prevent in the first place by criminalising it. ${ }^{20}$ The second argument is best expounded by $\mathrm{Ny}$ amu J in Republic v Kenya Revenue Authority ex parte Yaya Towers Limited ${ }^{21}$ where he stated that 'Illegality as to the formation of a contract implies that it is intended to be performed in an illegally prohibited manner and the courts cannot enforce it or provide any other remedies arising out of the contract as it is against Public Policy'. ${ }^{22}$ Consequently, receipt of proceeds of an illegality by the state amounts to the state aiding and abetting contravention of the law, as such contravening public policy.

In Mann $v \mathrm{Nash}^{23}$ in which an argument on the immorality of the taxation of tax profits was raised, Rowlatt $\mathrm{J}$ rejected it while asserting that:

'The Revenue representing the State, is merely looking at an accomplished fact. It is not condoning it; it has not taken part in it; it merely finds profits made from what appears to be a trade, and the Revenue laws happen to say that the profits made from trades have to be taxed, and they say: 'give us the tax'. It is not to the purpose in my judgment to say, 'but the same State that you represent has said they are unlawful.' That is immaterial altogether... It is said again: Is the State coming forward to take a share of unlawful gains?' It is mere rhetoric. The State is doing nothing of the kind; they are taxing the individual with reference to certain facts. They are not partners; they are not principals in the illegality, or sharers in the illegality; they are merely taxing a man in respect of those resources. I think it is only rhetoric to say that they are sharing in his profits, and a piece of rhetoric which is perfectly useless for the solution of the question which I have to decide'. ${ }^{24}$

17 Mann v Nash (1932), The United Kingdom Court of King's Bench; Scott v Brown (1892), The United Kingdom Court of King's Bench; Judge Manton's holding in Steinberg $v$ United States (1926), The United States Court of Appeals for the Second Circuit.

18 Republic v Kenya Revenue Authority ex parte Yaya Towers limited (2008) eKLR.

19 Bittker I, 'Taxing income from unlawful activities', Yale Law School, Faculty Scholarship Series, Paper 2289, 1974, $144-<$ http://digitalcommons.law.yale.edu/fss_papers/2289?utm_source=digital commons.law.yale.edupercent2Ffss_paperspercent2F2289\&utm_medium=PDF\&utm_campaign= PDFCoverPages> on 4 June 2016.

20 Judge Manton's holding in Steinberg v United States (1926), The United States Court of Appeals for the Second Circuit.

21 (2008) eKLR.

22 Republic v Kenya Revenue Authority ex parte Yaya Towers Limited (2008) eKLR.

23 Mann v Nash (1932), The United Kingdom Court of King's Bench.

24 Mann v Nash (1932), The United Kingdom Court of King's Bench. 
In Commissioner of Inland Revenue $v A k e n^{25}$ where the issue was whether income from prostitution was taxable, the court, despite questions on morality of the trade, proceeded to hold that the profits from prostitution were taxable and that the word 'trade' in itself has no connotation of lawfulness. ${ }^{26}$ Similarly, the Court in Southern (H.M. Inspector of Taxes) $v A B^{27}$ was of the view that irrespective of the illegality of the businesses in question, they nevertheless fit the meaning of trade as posited by the Act and that the profits therefrom were properly assessable to income tax. ${ }^{28}$

As Gupta argues, taxation, in theory, knows no morality ${ }^{29}$ neither is it, in theory, an issue of fairness, but of statutory application and that is the same for the taxpayer earning income from criminal activities, which constitute business, as it is of the ordinary legitimate taxpayer. ${ }^{30}$ The state does not tolerate crime, neither is it a silent partner to crime by taxing proceeds of illicit trade. ${ }^{31}$ As expounded by Rowlatt J, the state is merely looking for an accomplished fact, which arises from application of express provisions of the law. ${ }^{32}$ A dollar of profit from an unlawful activity will buy as much as a dollar from a lawful activity. ${ }^{33}$ Taxing legal income while exempting illegal income is tantamount to incentivising an illegality, which would in turn be contrary to public policy and not vice versa. In any case, refraining from taxing ill-gotten gains would amount to exempting persons from one law simply because they have violated another. ${ }^{34}$

In Sullivan $v$ United States where a matter of this nature was addressed, the court ruled that there is no justice in taxing persons in legitimate enterprises while allowing those who thrive by violation of the law to escape. ${ }^{35}$ If indeed the government wants to disincentivise illegal trade, it makes perfect sense both

25 Mann v Nash (1932), The United Kingdom Court of King's Bench.

26 Commissioner of Inland Revenue v Aken (1988), The United Kingdom Queen's Bench Division of the High Court.

27 Southern (H.M Inspector of Taxes) v AB (1933), The United Kingdom Court of King's Bench.

28 Southern (H.M Inspector of Taxes) v AB (1933), The United Kingdom Court of King's Bench.

29 In Commissioner v Wilcox (1946), The Supreme Court of the United States, the court posited as follows; 'Moral turpitude is not a touchstone of taxability. The question, rather, is whether the taxpayer in fact received a statutory gain, profit or benefit. That the taxpayer's motive may bave been reprehensible or the mode of receipt illegal has no bearing upon the application of 22 (a)'.

30 Gupta R, 'Taxation of illegal activities in New Zealand and Australia' 3 (2) Journal of the Australasian Tax Teachers Association 2, 2008106.

31 Mann v Nash (1932), The United Kingdom Court of King's Bench.

32 Mann v Nash (1932), The United Kingdom Court of King's Bench.

33 Bittker I, 'Taxing income from unlawful activities', 137.

34 Lusty D, 'Taxing the untouchables who profit from organized crime' 10 Journal of Financial Crime3, 2003, 2.

35 Sullivan $v$ United States (1927), The Supreme Court of the United States. 
legally and economically to then tax proceeds of crime rather than grant them a tax exemption. In any case exempting from tax, income derived from illegal activity in order to discourage the public from engaging in such is a needlessly blunt instrument to say the least. ${ }^{36}$ Moreover, it beats logic to think that a legislature in its right mind would ever want to incentivise crime at the expense of law-abiding citizens. ${ }^{37}$ In Kenya's scenario, the Act makes no distinction between legally or illegally derived incomes. ${ }^{38}$ Consequently, provided an amount falls within the definition of assessable income, regardless of its legal or illegal roots, it makes perfect sense to subject it to tax. This has been the case in several other tax jurisdictions faced with questions pertaining to taxability of illegal income. In the United States, Congress, pursuant to the Sixteenth Amendment ${ }^{39}$ is empowered to levy and collect taxes from all income from whatever source derived. ${ }^{40}$ The Internal Revenue Code further defines gross income to include all income from whatever source derived except where provided otherwise. ${ }^{41}$ The courts on numerous occasions have interpreted these provisions to include income derived from illegal activities. ${ }^{42}$ To state but a few:

In Sullivan $v$ United States ${ }^{43}$ where the court held that gains derived from illicit traffic were taxable income under the 1921 Internal Revenue Act, Justice Holmes ruled that they see no reason why the fact that a business is unlawful should exempt it from paying taxes that if lawful it would have to pay. ${ }^{44}$ In Rutkin $v$ United States ${ }^{45}$ where the defendant was involved in extortion of funds, the Supreme Court held that both lawful and unlawful gain constituted taxable income provided its recipient (the criminal) has control over the gain and derives realizable economic value from it. ${ }^{46}$ In James $v$ United States, ${ }^{47}$ where the petitioner embezzled large sums of money during the years 1951 through 1954 and, failed to report those amounts as gross income in his income tax returns for those years, the Supreme Court held that the embezzler was required to include his ill-gotten

\footnotetext{
36 Bittker I, 'Taxing income from unlawful activities', 140.

37 Sullivan v United States (1927), The Supreme Court of the United States.

38 Section 3(1), Income Tax Act (Chapter 470).

39 16th Amendment, United States Constitution.

40 16th Amendment, United States Constitution.

41 Sec 61(a), Internal Revenue Code (United States).

42 Sullivan $v$ United States (1927), The Supreme Court of the United States; Rutkin v United States (1952), The Supreme Court of the United States; James v United States (1961), The Supreme Court of the United States.

43 Sullivan v United States (1927), The Supreme Court of the United States.

44 Sullivan $v$ United States (1927), The Supreme Court of the United States.

45 Rutkin v United States (1952), The Supreme Court of the United States.

46 Rutkin v United States (1952), The Supreme Court of the United States.

47 James $v$ United States (1961), The Supreme Court of the United States.
} 
gains in his 'gross income' for federal income tax purposes. ${ }^{48}$

The courts in South Africa have adopted a similar position. In CIR v Delagoa Bay Cigarette $\mathrm{Co}^{49}$ where an issue of taxability of proceeds of an illegality was raised, the court held that the legality or illegality of the source of income was immaterial..$^{50}$ In reaching this decision, it was guided by the holding in Partridge $v$ Mallandaine ${ }^{51}$ where profits of a betting business were held to be taxable as income tax. ${ }^{52}$ In MP Finance Group CC (in liquidation) v C: $S A R S^{53}$ where perpetrators were operating an illegal investment enterprise, ${ }^{54}$ the Supreme Court held that an illegal contract is not without all legal consequences, and it can have fiscal consequences before proceeding to hold that the amount received by the perpetrators constituted receipts within the meaning of the Income Tax Act of South Africa. ${ }^{55}$

In conclusion, income derived from illicit activities does meet the definition of income within the Income Tax Act of Kenya. Levying such proceeds contravenes no public policy; in fact, it is in the interest of the public that such income be subjected to tax. This a position that has been adopted by several other tax jurisdictions, as depicted above; therefore Kenya should follow suit.

\section{Deductibility of Expenses Incurred in the Process of Generation of Illegal Income}

As stated earlier, taxing proceeds of crime opened a plethora of issues, which the courts may not have anticipated when reaching this conclusion. Deductibility of expenses incurred in the generation of illegal income is one such issue. If a career looter were to pay taxes, can he deduct 'kickbacks' as an ex-

48 The court was guided by the definition of gross income in Commissioner of Internal Revenue v Glenshaw Glass Co. (1955) where the Supreme Court of the United States held that taxpayers had gross income when they had 'an accession to wealth, clearly realized, and over which the taxpayers have complete dominion.

49 CIR v Delagoa Bay Cigarette Co (1918), The Supreme Court of South Africa.

$50 \quad$ CIR $v$ Delagoa Bay Cigarette Co (1918), The Supreme Court of South Africa.

51 Partridge v Mallandaine (1886), The United Kingdom Queen's Bench Division of the High court.

52 More specifically in the words of Denman J in Partridge $v$ Mallandaine (1886), 'even the fact of a vocation being unlawful could not be set up against the demand for income tax'.

53 MP Finance Group CC (in liquidation) v C: SARS (2007), The Supreme Court of Appeal of South Africa.

54 In other words, a pyramid scheme.

55 MP Finance Group CC (in liquidation) v C: SARS (2007). 
penditure incurred in the process of looting? $?^{56}$ Alternatively, in the words of Hely $\mathrm{J}$ in Commissioner of Taxation $v$ La Rosa ${ }^{57}$ can a paid assassin deduct the cost of his bullets and depreciate the cost of his gun as an expense incurred in the generation of income? ${ }^{58}$ The expenses incurred in this context are of two types: one, criminal or illegal expenses; and two, expenses which are legitimate despite the business or activity being illegal. ${ }^{59}$

There is a high likelihood, given that the income in question is derived from illegal activity that the accruing expenses are illegal as well; after all, the fruits of a forbidden tree are also forbidden but this does not preclude the possibility of expenses legal in their nature being incurred in the generation of the same income. In Heininger $v$ Commissioner, ${ }^{60}$ a seventh-circuit court ruled that the fact that an expense is remotely related to an illegal act does not bar deduction. ${ }^{61} \mathrm{~A}$ good example of a deduction legitimate in its nature that may be incurred by an illegal trade is the cost of criminal litigation where matters pertaining to the said business come before the court. ${ }^{62}$

In Kenya, the Income Tax Act provides that all expenditure, subject to Section 16, incurred during the year of income, wholly and exclusively in the process of generation of income, are allowable deductions. ${ }^{63}$ Whereas it further enumerates several deductible expenses as well as non-deductibles under Section 16, it does not expressly forbid deduction of illegal expenses. Moreover, with regard to a business, Section 3 of the Income Tax Act stipulates that it is the gains and profits that constitute the chargeable income not the whole income. ${ }^{64}$ Profits and gains of a business can only be ascertained after the expenditure incurred has been deducted from the gross income. ${ }^{65}$

In the case of Income Tax $v T L_{t} d^{66}$ the court posited that for an item of expenditure to be deductible under circulating capital, it must have been incurred

\footnotetext{
Lilly v Commissioner (1952), The Supreme Court of the United States.

Commissioner of Taxation v La Rosa (2003), The Federal Court of Australia.

Lund S, 'Deductions arising from illegal activities'13(1) Revenue Law Journal, 2003, 1.

59 Bittker B, 'Taxing income from unlawful activities' 146; Tabbach A, 'Criminal behavior: Sanctions and income taxation: An economic analysis' John M. Olin Program in Law and Economics, Working Paper Number 169, 2002, 5 ; Bovingdon G, 'Deducting the expenses of an illegal business' 19(2) Montana Law Review, 1958, 142.

${ }^{60}$ Heininger $v$ Commissioner (1952), The United States Court of Appeals for the Seventh Circuit.

${ }_{61}$ Further referenced in Bovingdon G, 'Deducting the expenses of an illegal business', 142.

62 United States v Gilmore, The Supreme Court of the United States.

63 Section 15, Income Tax Act (Chapter 470).

${ }_{64}$ Section 3(2)(a), Income Tax Act (Chapter 470).

65 Commissioner of domestic taxes $v$ Kenya Maltings Limited (2013) eKLR.

66 Income Tax v T Ltd (No. 2) EA (1971) 569.
} 
for the direct purpose of producing profits. In Commissioner of Domestic Taxes v Kenya Maltings Limited ${ }^{67}$ the court was of the view that the real reason of expenses being looked at is to determine whether the same amounted to capital expenditure or expenses wholly or exclusively incurred for the production of income. In reaching this decision the court was guided by the holding in Hancock $v$ General Reversionary and Investment Company ${ }^{68}$ where Lush J. held that the test applicable in ascertaining deductibility of an expense is whether the expenditure was incurred in order to meet a continuing business demand or was it incurred once and for all. In the former, the expense should be treated as an ordinary business expense in which case it will be deductible, while in the latter it should be treated as a capital expense which is non-deductible. ${ }^{69}$

Evident from the above court decisions and interpretation of Section 15 of the Income Tax Act, there are two considerations requisite in ascertaining whether an expense is deductible or not. One, is the amount in question revenue or capital in nature? ${ }^{70}$ And two, have they been incurred wholly and exclusively for furtherance of business? The scope of this article is confined to expenses incurred wholly and exclusively for furtherance of business thus meeting both considerations of the Act but tainted by the illegality of its accruing business.

The Act adopts the phrase all expenditure incurred in the process of income generation. ${ }^{71}$ Save for the provisions of Sections 16 and 27, as well as the considerations alluded to in the preceding page, the Act does not qualify the nature of the said expenses, they may well be legal or illegal. Nonetheless, whereas both legitimate expenses and criminal expenses incurred in the process of illegal revenue generation might fall under the purview of section 15, criminal expenses such as bribes may fail the public policy test, ${ }^{72}$ so is the case with fines and penalties.

(2013) EKLR

68 Hancock $v$ General Reversionary and Investment Company (1919), The United Kingdom Court of King's Bench.

69 Hancock $v$ General Reversionary and Investment Company (1919), The United Kingdom Court of King's Bench as quoted in Commissioner of Domestic Taxes v Kenya Maltings Limited (2013) eKLR at paragraph 34.

70 According to the Income Tax Act of Kenya, income of a capital nature is subject to a withholding tax as opposed to revenues which are subject to income tax. Income tax is considerably high compared to the rate at which withholding tax is levied in Kenya.

71 Section 15, Income Tax Act (Chapter 470).

72 Tabbach A, 'Criminal behavior: Sanctions and income taxation: An Economic Analysis' 16. 
Lord Hoffman in the case of McKnight v Sheppard ${ }^{13}$ best enunciated the reason for non-deductibility of fines and penalties by positing as follows: 'Its purpose is to punish the taxpayer and a court may easily conclude that the legislative policy would be diluted if the taxpayer were allowed to share the burden with the rest of the community by a deduction for the purposes of $\operatorname{tax} .{ }^{74}$ In the case of Tank Truck Rentals Inc. $v$ Commissioner ${ }^{75}$ as well as in Hoover Motor Express Co. Inc. $v$ United States $^{76}$ where an issue as to deductibility of fines arose, the courts were of the view that the state statutes which had been violated were expressions of public policy, therefore deductibility of fines would equally be a contravention of public policy as it is of the state statutes. ${ }^{77}$

The Constitution, under Article ten elucidates the various principles and values binding upon all state organs, state officers, public officers and all other persons when enacting, applying or interpreting any law or making any public policy decisions. ${ }^{78}$ The rule of law, accountability, transparency and integrity etc. are some of the values and principles applicable. ${ }^{79}$ The Income Tax Act, being a law of Kenya, is subject to the above stipulations of the Constitution. ${ }^{80}$ Therefore, whereas illegal expenses might fall under the purview of 'all expenditure' in accordance with Section 15 of the Income Tax Act, that in itself is not the only applicable test in determining deductibility. State organs, pursuant to Article ten of the Constitution are under an obligation to take into consideration the various values and principles posited therein in interpreting Section 15 of the Income Tax Act. Therefore, despite illegal expenses meeting the stipulations detailed under Section 15 of the Act on deductibility, they may very well be found to be non-deductible on public policy grounds as long as in so doing, the values and principles enunciated under Article 10 of the Constitution are taken into consideration. Justice Ringera in the case of Christ for All Nations v Apollo Insurance Co. $L t d^{81}$ was of the view that whereas public policy is a broad concept incapable of a precise definition, its contravention may be proved if any of the following is shown; inconsistency with the Constitution or other laws of Kenya, whether

\footnotetext{
McKnight v Sheppard (1999), The United Kingdom House of Lords.

McKnight v Sheppard (1999), The United Kingdom House of Lords.

Tank Truck Rentals Inc. v Commissioner (1958), The Supreme Court of the United States.

Hoover Motor Express Co. Inc. v United States (1958), The Supreme Court of the United States.

Analysed in depth in Deustch J (ed.), 'Business expenses, disallowance, and public policy: Some problems of sanctioning with the internal Revenue Code' 72 The Yale Law Journal, 1962, 116 $<$ http://www.jstor.org/stable/pdf/794544.pdf $>$ on 15 December 2016.

78 Article 10(1) (b), Constitution of Kenya (2010).

Article 10(2), Constitution of Kenya (2010).

Article 2(1), Constitution of Kenya (2010).

(2002) 2 EA 366.
} 
written or unwritten; or inimical to the national interest of Kenya; or contravention of justice or morality. ${ }^{82}$

Criminal or illegal expenses of an illegal business are, in their nature and not because of their roots, a contravention of the law. Paying a bribe to a public official for example is a contravention of the Constitution, ${ }^{83}$ the Public Officers Ethics Act ${ }^{84}$ as well as the Anti-Corruption and Economic Crimes Act. ${ }^{85}$ Therefore, like other illegal expenses, it contravenes the laws of Kenya. Consequently, allowing such an expense to be deducted as a deductible expense would not only be aiding contravention of the state laws but of public policy as well. Public policy demands that whether or not a given illegal expense fits the bill of a deductible expense under the Act, it should not be allowed for two reasons; one, though not a contravention of the Income Tax Act, the given expense is a contravention of other laws of Kenya; two, allowing such a deduction would be inimical to the national interest as well as a contravention of justice and morality. In any case, as posited by Lord Mansfield in Holman v Johnson ${ }^{86}$ no court would aid a man who founds his cause of action upon an immoral or illegal act.

In the United States, where the Internal Revenue Code under section 162 allows deduction of 'all the ordinary and necessary' expenses paid and incurred during the taxable year in carrying on a business, the courts have often declared that illegal expenses could never be necessary since it is never necessary nor ordinary to violate the law while conducting business. ${ }^{87}$ This position has often been met with the criticism that the primary role of the tax act is taxation and not penalising violations already penalised under a primary statute. ${ }^{88}$ The proponents of this argue that disallowance of illegal expenses amounts to an additional sanction imposed without warrant of the primary statute, which created the offense and the sanction. ${ }^{89}$ These criticisms are self-defeating for two reasons: one, whereas it is not the function of the Income Tax Act to penalise violations already penalised

\footnotetext{
Christ for All Nations v Apollo Insurance Co. Ltd (2002) 2 EA 366.

Article 75(1), Constitution of Kenya (2010); Section 9, Public Officers' Ethics Act (Act No 4 of 2003).

Section 9 \& 11, Public Officers' Ethics Act(Act No 4 of 2003).

Section 39 \& 46, Anti-corruption and Economic Crimes Act (Act No 3 of 2003).

Holman v Johnson (1775), The United Kingdom Court of King's Bench.

Commissioner v Heininger (1943),The Supreme Court of the United States; Burrougbs Building Material Company v Commissioner (1931), The United States Court of Appeals for the Second Circuit; Gallatin Farmers Company v Commissioner (1942), The United States Court of Appeals for the Ninth Circuit; Israel Silberman v Commissioner (1941), The United States Board of Tax Appeals.

88 Deustch J (ed.), 'Business expenses, disallowance, and public policy: some problems of sanctioning with the internal revenue code' 72 The Yale Law Journal, 1962,128.

89 Deustch J (ed.), 'Business expenses, disallowance, and public policy: some problems of sanctioning with the internal revenue code' 72 The Yale Law Journal, 1962,128.
} 
under the primary statute, allowance of these expenses would be a direct frustration of the prohibiting statute..$^{90}$ This would be tantamount to giving that which is requested by the law on the one hand while taking it back with the other hand. Two, allowance of such deductions would in itself amount to the state countenancing breach of the rule of law. ${ }^{91}$ The effect of a deduction is reducing the taxpayer's liability or burden. Should illegal expenses be deductible not only will the state be nullifying the effect of the primary statute which criminalised the said expenses but also incentivising commission of acts leading up to the expenses in question by reducing liability for engagement in acts giving rise to these expenses. This is contrary to the spirit and rule of law. On the other hand, legitimate expenses of an illegal business have often been held to be deductible. In $G A$ Comeaux,${ }^{92}$ where a tax payer sought to deduct protection payments as well as salaries and miscellaneous expenses from the taxable income of an illegal enterprise, the tax court disallowed deduction of protection payments but allowed deduction of salaries and miscellaneous expenses terming them as legitimate expenses of an illegitimate trade. While reaching this conclusion, the court noted that the income tax is not a tax on gross income, even where the income is earned in an illegal business. Further, the court ruled that deductibility of expenses of such a business is dependent on the innate character of the specific expense itself.

The Tax Court was faced with a similar question in the case of Charles v Doyle ${ }^{93}$ in which a bookmaker had sought to have an amount paid in form of wages and rent deducted as part of the expenditure despite bookmaking being prohibited by the laws of Illinois. Similar to the holding in Comeaux, the court found them to be legitimate expenses of an illegitimate business thus deductible. The Supreme Court of the United States in Commissioner v Sullivan further buttressed this position ${ }^{94}$ when it reaffirmed deductibility of wages and rents as ordinary and necessary expenses of an illegal business. The Court further held that expenses falling under the description 'ordinary and necessary expenses' in accordance with Section 162 of the Internal Revenue Code, are deductible unless the allowance; is a device to avoid the consequence of violation of the law, or such an allowance would be contrary to federal policy as expressed in a statute or regulation.

\footnotetext{
Tank Truck Rentals Inc. v Commissioner (1958), The Supreme Court of the United States.

Contrary to Article 10, Constitution of Kenya(2010).

G. A Comeaux Case (1948), The United States Tax Court.

Charles v Doyle (1954), The United States Tax Court.

Commissioner v Sullivan (1958), The Supreme Court of United States.
} 
In conclusion, evident from the wording of section 3(2) and section 15 of the Income Tax Act, only the net income, otherwise known as profits and gains, of a business constitute the taxable income. ${ }^{95}$ At no place does the Act allude to the gross income being taxable. Over and above the stipulations of the Income Tax Act, the Constitution obliges state organs as well as officers while interpreting or applying any law to consider various principles among them the rule of law and national interest. ${ }^{96}$ Resulting therefrom the courts as well as the Commissioner for Tax or KRA are under an obligation to interpret section 3 and 15 of the Income Tax Act in a manner which is in line with public policy and the rule of law. Whereas both legitimate expenses and illegitimate expenses of an illegal business meet the stipulations of the Act, illegitimate expenses fail the public policy test. As such legitimate expenses of an illegal business should be deductible while illegitimate expenses are non-deductible.

\section{Taxation of Illegal Income and the Right Against Self- Incrimination}

One of the criticisms that can be levelled against the taxation of illegal income is the violation of the right against self-incrimination. If a person is compelled to file a tax return and pay taxes on illegal income, they might incriminate themselves in a criminal activity. This requirement may run a foul of the constitutional right against self-incrimination, as a person may disclose information which may be later used against him. This is specially the case if the information is used in non-tax law criminal cases. The right against self-incrimination is meant to protect the accused person to such an extent that they are not forced or required to give evidence that will affect them negatively. It stands to reason that any disclosure through tax returns of income from an illegal activity is an assertion that the person has committed an illegal act. The person therefore incriminates himself. The Constitution of Kenya ${ }^{97}$ guarantees the right of an arrested person against self-incrimination. ${ }^{98}$ This right is encompassed in the right to a fair hearing which is one of the rights which cannot be limited. ${ }^{99}$ This right is also

\footnotetext{
Commissioner of Domestic Taxes v Kenya Maltings Limited (2013) eKLR.

Article 10, Constitution of Kenya (2010).

Article 2, Constitution of Kenya (2010).

Article 50(2)(1), Constitution of Kenya (2010).

Article 25, Constitution of Kenya (2010).
} 
protected by international instruments as an aspect of the right to a fair trial. ${ }^{100}$ The Evidence Act also provides for the protection of accused persons against self-incrimination in Section 128. ${ }^{101}$

On various occasions, the courts in Kenya have had to grapple with the right against self-incrimination though never in the circumstances of a tax related case. Under the repealed Constitution, the right against self-incrimination was discussed in the case of Christopher Ndarathi Murungaru v Kenya Anti-Corruption Commission \& Another. ${ }^{102}$ The court stated that the requirement by the Kenya Anti-Corruption and Economic Crimes Act, that a person who is under investigation for corruption must give information about all their property and how they acquired it, was not in violation of the person's right against self-incrimination. Under this law, one was required to omit to the investigator information that would effectively incriminate him in illegal activity. The court held that this law was constitutional. This reasoning can be applied to the tax laws to find that the requirement that a person who files tax returns listing their illegal income does not violate their right against self-incrimination. Moreover, the court held that this right is only available to persons once they have been arrested and not before then. Hence if one has not been arrested or is not involved in a court proceeding they will not be able to claim the right against self-incrimination.

Under the new constitutional dispensation, the question of self-incrimination has once again been dealt with by the High Court in the case of Richard Dickson Ogendo \& 2 others v Attorney General \& 5 others. ${ }^{103}$ In this case, Justice Majanja found that an accused person's right against self-incrimination concerns the giving of oral or documentary testimony against himself or herself. Moreover, the purpose of this protection is to protect the accused person from giving information that has been obtained through coercion or unfair means. ${ }^{104}$ Justice Majanja further explained the purpose of the protection against self-incrimination by quoting the US case of Miranda v Arizona where the justices stated:

'All these policies point to one overriding thought: the constitutional foundation underlying the privilege is the respect of a government, state or federal, must accord to the dignity and integrity of its citizens. To maintain a 'fair state-individual balance, to require the government to shoulder the entire load' to respect the inviolability of the human personality, our accusatory system of criminal justice demands that the gov-

\footnotetext{
Article 14, International Convention on Civil and Political Rights, 19 December 1966.

Section 128, Evidence Act (Chapter 80).

Christopher Ndarathi Murungaru v Kenya Anti-Corruption Commission \& Another (2006) eKLR.

Richard Dickson Ogendo \& 2 others v Attorney General \& 5 others (2014) eKLR.

Richard Dickson Ogendo \& 2 others v Attorney General \& 5 others (2014) eKLR.
} 
ernment seeking to punish an individual produce the evidence against him by its own independent labours, rather than by the cruel, simple expedient of compelling it from his own mouth. ${ }^{105}$

Kenyan law has not specifically dealt with the issue of self-incrimination in the case of taxation of illegal income. It is therefore instructive to look at other jurisdictions. One of the jurisdictions that have dealt with this issue is the United States. In the case of United States $v$. Sullivan, ${ }^{106}$ the court dealt with the taxation of income from the illegal liquor trade, as this was during the prohibition. The defendant, Sullivan had refused to file tax returns claiming that by doing so, his right against self-incrimination would be violated. When the case reached the Supreme Court, this court held that the defendant could not refuse to file the tax return. Everyone is required to file their return but they can claim the privilege of the protection of the right against self-incrimination at the moment of filing the returns. The court held that one can refuse to answer certain questions in return or find other ways to claim the privilege provided by the Fifth Amendment. In the case of Garner $v$ United States, ${ }^{107}$ the court had to grapple with the issue whether the prosecutor in a non-tax related criminal case could use tax returns. In this case, the prosecution presented the accused person's tax return where he had indicated that his income was from gambling in a case against him for the offense of gambling. In the court of first instance, Garner was convicted based on the evidence adduced. On appeal, the Court of Appeal found that the accused person was not given protection against self-incrimination. The Court of Appeal held that 'submitting to the statutory compulsion to disclose information in an income tax return did not constitute a voluntary waiver of Fifth Amendment protections.' 'The court held that the government should prove its case without using the defendant's tax returns as evidence but the government can use these returns in further tax related prosecutions. At the Supreme Court the court held that the accused person had waived his right against self-incrimination as he could have claimed the privilege of the Fifth Amendment at the time of filing the returns. Generally, the Supreme Court stated that at the point of filing the returns, the defendant could have claimed the privilege against self-incrimination. This means that this avenue is available to those who are filing returns on illegal income.

\footnotetext{
105 Miranda v Arizona (1996), The Supreme Court of the United States.

106 United States v Sullivan (1927), The Supreme Court of the United States.

107 Garnerv United States (1976), The Supreme Court of the United States.
} 
If Kenya is to begin taxing illegal income, it needs to ensure that adequate protection is given to all persons. There are two possible ways of ensuring this balance of the government's need to collect tax even from illegal income and the right against self-incrimination. These approaches were dealt with to some degree in the case of Garner $v$ US in the different courts. The first method is the restriction approach which was used by the Court of Appeal in this case. ${ }^{108}$ According to this method, in order to protect the accused person, the government is limited in the instances where it can use compelled information that can incriminate a person. Generally, the government will not be able to use the tax returns that the taxpayer has filed during consequent non-tax criminal cases. ${ }^{109}$ Therefore, if a person has admitted to having income from an illegal source, the government cannot use the person's tax returns to prove the person's involvement in that illegal activity.

The second approach, which was alluded to in the Supreme Court judgment ${ }^{110}$ is simply having provisions where a person can raise the privilege of self-incrimination when filing the tax returns. This can be done by allowing a person to refuse to answer question regarding their source of their income. Alternatively, there could be a section of Miscellaneous Income where income from illegal activities is simply termed as miscellaneous income. ${ }^{111}$ All this should be done in order to protect persons whose source of income is an illegal activity.

In the authors' view, Kenya should adopt a hybrid method which incorporates both approaches. Simply put, taxpayers should be allowed to raise the privilege of the right against self- incrimination when revealing their source of income if it is from an illegal act. At the same time, ambitious prosecutors should still be stopped by law from adducing evidence against taxpayers in subsequent non-tax criminal cases by presenting the taxpayers' returns as evidence against them. The authors are of the view that the hybrid system is necessary as the current state of affairs as set out in Section 128 of the Evidence Act is not sufficient. Currently, what happens in Kenya, is that a witness must answer all questions that they are asked during a hearing, even if there are incriminatory. Their evidence, however, will not be used against them in a later trial. However, from the wording of Section 128 the Evidence Act, it is not clear whether the protection

\footnotetext{
108 Garner v United States (1972), The United States Court of Appeals for the Ninth Circuit.

109 Bucci A, 'Taxation of illegal narcotics: a violation of the fifth amendment rights or an innovative tool in the war against drugs?' 11(3) Journal of Civil Rights and Economic Development, 1996, 774.

110 Garnerv United States (1976), The Supreme Court of the United States.

111 Alemu Y, 'Taxing crime: the application of Ethiopian income tax laws to incomes from illegal activities' 4(1) Jimma University Journal of Law, 2012, 173.
} 
against self-incrimination extends to documentary evidence. The hybrid system will therefore better protect the constitutional rights of the accused person because a prosecutor in a later case will not be able to produce the accused person's tax returns as evidence of criminal activity. Moreover, if such tax returns are admissible, the source of the income will not be clearly stated, as it will be under a generic source of income.

\section{Use of Tax Law to Reinforce Criminal Law}

The final issue for consideration is whether the government can use tax as a tool to try and reduce crime. Tax is a tool generally used by governments to 'raise revenue, to provide incentives or disincentives for certain activities and to correct market failures'. ${ }^{112}$ The imposition of taxes or tax subsidies is also used by governments to enforce its policies such as redistribution of wealth between the rich and the poor. ${ }^{113}$ In order to encourage a struggling sector, the government can decide to lower tax on the goods or services produced by that sector. In 2014, an interesting amendment was made to the Income Tax Act, ${ }^{114}$ through the Finance Act $2014 .{ }^{115}$ The amendment was meant to exempt from the definition of taxable income any expenditure on vacation trips to destinations in Kenya that are paid by the employer on behalf of his employees and immediate family. This exception was to apply until $1^{\text {st }}$ July $2015 .{ }^{116}$ This was meant to encourage local tourism and to boost the tourism sector. The government also uses tax as a tool whenever it wants to discourage the consumption of certain goods or services. The issue therefore is whether the taxation of income from illegal activities can be used as a tool to discourage criminal activities and lower the crime rate.

Illegal activities are a source of profit to those who engage in such activities. It is therefore assumed that if one removes the profit from such activities, there would be fewer reasons for committing crimes. ${ }^{117}$ Thus taxing illegal activities will lead to a decrease in crime. In the United States, taxation has been used to a

112 Prasad N, 'Policies for redistribution: the use of taxes and social transfers'International Institute for Labour Studies, Discussion Paper Number 194, 2008, 6 - <http://www.oit.org/wcmsp5/groups/ public/---dgreports/---inst/documents/publication/wcms_193159.pdf $>$ on 15 December 2016.

113 Prasad N, 'Policies for redistribution: The use of taxes and social transfers,'1.

114 Income Tax Act (Chapter 470).

115 Finance Act (Act No 16 of 2014).

116 Section 5, Finance Act (Act No 16 of 2014).

117 DeMattei K, 'The use of taxation to control organized crime' 39 California Law Review, 1951, 226-227 - <http://scholarship.law.berkeley.edu/californialawreview/vol39/iss2/4> on 15 August 2016. 
certain degree to control criminal activities. Tax has been used in the fight against organised crime, where tax is used to gain access to the large amount of money raised through organised crime. ${ }^{118}$ It has been seen that for this to be used effectively as a tool to discourage crime, these taxes must be enforced. Moreover, it is better to first ensure that the leading criminals or heads of criminal organisations are forced to pay taxes. In the United States after Al Capone was convicted, many other gangsters began to pay taxes including their back taxes. ${ }^{119}$ Thus it can be assumed that it resulted in their crimes being less lucrative.

Tax has also been used as a tool to help the law enforcement authorities catch certain criminals when all else fails. It was used in the United States of America with the famous criminal Al Capone in the 1930s. ${ }^{120}$ In this case, Al Capone was prosecuted and convicted for federal tax evasion instead of the crimes he was suspected of, such as bootlegging, prostitution, gambling and assault. ${ }^{121}$ In this instance, tax proved to be an important tool in fighting crime.

In the Kenyan jurisdiction, therefore, the imposition of taxes on criminal activities may prove to be a useful tool in fighting crime. This is because it will make crime less profitable with those engaging in these illegal activities being forced to pay taxes. Moreover, the law enforcement agencies may be able to charge the persons involved in illegal activities with tax evasion if they do not pay taxes. This will interrupt their activities and reduce the crime rate.

\section{Conclusion}

Illegal income, pursuant to section 3 of the Income Tax Act of Kenya is taxable, a position reiterated by the Court in Kenya Revenue Authority v Yaya Towers Limited. The contrary would not only entitle a wrong doer to benefit from his/ her illegal transactions but further exempt him/her from paying taxes. Moreover, honest taxpayers would be incentivised to taint their businesses with an illegality with a view of benefiting from such an exemption. Failure to tax illegal income does not further public policy but rather contravenes it.

Income tax pursuant to section 3(2) and 15 of the Income Tax Act, is levied on the profits and gains of a business not the gross income. As such if income

\footnotetext{
DeMattei K, 'The use of taxation to control organized crime,' 233.

19 DeMattei K, 'The use of taxation to control organized crime,'234.

120 Bittker I, 'Taxing income from unlawful activities,' 130.

121 <http://www.history.com/topics/al-capone> on 15 August 2016.
} 
from illegal activity is taxable then such taxes shall apply not on the gross income but rather on the profits and gains of such activity. Nonetheless, Article ten of the Constitution obliges state organs and state officers while interpreting or applying any law to consider various principles among them the rule of law and the national interest. Deducting illegitimate expenses contravenes the nation's interest as well as public policy which is not the case with legitimate expenses. As such legitimate expenses of an illegal business should be deductible while illegitimate expenses are non-deductible.

Imposition of tax on illegal activities can prove to be a useful tool for the government to help it collect more revenue and even indirectly decrease crime by making illegal activities less profitable. This can also lead to a more equitable distribution of the burden of taxation amongst all citizens as envisioned by the Constitution. When the government is taxing illegal income, however, it must ensure that there are sufficient safeguards to protect the rights of persons engaging in such activities, especially their right against self-incrimination. The government should therefore publish rules and guidelines to clarify how these taxes will be collected. These rules should provide adequate protection to all persons and deal with topics such as deductions of expenses. 